Article

\title{
Grain Quality and Allelic Variation of the Badh2 Gene in Thai Fragrant Rice Landraces
}

\author{
Phukjira Chan-in ${ }^{1}$, Sansanee Jamjod ${ }^{1,2}$, Narit Yimyam ${ }^{3}$, Benjavan Rerkasem ${ }^{1}$ and \\ Tonapha Pusadee 1,4,*D \\ 1 Plant Genetic Resource and Nutrition lab (CMUPNlab), Department of Plant and Soil Science, Faculty of \\ Agriculture, Chiang Mai University, Chiang Mai 50200, Thailand; phukjira_c@cmu.ac.th (P.C.-i.); \\ sansanee.j@cmu.ac.th (S.J.); benrerkasem@gmail.com (B.R.) \\ 2 Research Center for Development of Local Lanna Rice and Rice Products, Chiang Mai University, \\ Chiang Mai 50200, Thailand \\ 3 Department of Highland Agriculture Natural Resources and Environment, Faculty of Agriculture, \\ Chiang Mai University, Chiang Mai 50200, Thailand; narit.y@cmu.ac.th \\ 4 Innovative Agriculture Research Center, Faculty of Agriculture, Chiang Mai University, Chiang Mai 50200, \\ Thailand \\ * Correspondence: tonapha.p@cmu.ac.th; Tel.: +66-85-375-8160
}

Received: 17 April 2020; Accepted: 29 May 2020; Published: 30 May 2020

check for updates

\begin{abstract}
Fragrance, which plays an important role in determining the economic value of rice to growers and consumers, is known to be controlled by the Badh2 gene. This study evaluated the grain quality characteristics and allelic variation of the Badh2 gene in 22 fragrant rice landraces from Thailand. The rice seed samples from farmers' storage facilities in northern, northeastern and southern Thailand, plus two advanced breeding lines and three check varieties, were evaluated for seed morphology and grain quality, and their Badh2 genes covering intron 4 to intron 8 were re-sequenced. Almost all of the landraces were classified as large grain types, with medium to high gelatinization temperatures. The variation in the Badh2 gene by haplotype analysis correlated with grain aroma by sensory evaluation. The badh2-E7 was found in haplotype 1 with a strong aroma in KH, NDLP, and PLD, as in KDML105 and the moderately aromatic BNM-CMU, BNM4, and SKH, along with PTT1. Three haplotypes had different positions of SNP on the Badh2 gene with varying results in the sensory test. The present results suggest that some rice varieties could be potentially introduced as genetic resources for fragrant rice breeding programs or could be developed to highly palatable cultivars with geographical indications to increase the income of highland farmers.
\end{abstract}

Keywords: aromatic rice; local variety; gelatinization temperature; badh2-E7 allele

\section{Introduction}

The eating quality of rice, also known as rice palatability, is a very important factor that determines the economic value of rice for producers and consumers - the aroma of rice plays a significant part of this. Fragrant rice is quality rice with a good taste, softness, and a unique aroma, making it very popular [1]. Aromatic or fragrant rice is the most expensive rice in the global rice market [2-4]. Among the numerous volatile compounds associated with the aroma in rice, the main aromatic compound has been identified as 2-acetyl-1-pyrroline (2AP) [5], produced under the control of the recessive gene $B a d h 2$ [6-8]. In aromatic rice genotypes, there is an eight base-pairs deletion in exon 7 of the Badh2 gene [9], but with the 2AP concentration and aroma varying greatly depending on the environment [10]. The most widely known aromatic rice are Basmati rice of India and Pakistan [2], and Thailand's Hom Mali [11]. Basmati, with extra-long slender grains of soft and fluffy texture when cooked, belongs to the japonica group, have while Hom Mali and other jasmine type varieties, with long 
slender grains, soft and moist texture when cooked, are more closely with the indica group [12]. In spite of their distinctive grain quality features, the Badh2 gene and 2AP are common to both groups of aromatic rice. Most of India's Basmati rice is grown from the variety Pusa Basmati 1121 [13], while Thai Hom Mali, a worldwide registered trademark [14], is required by law to be grown from the traditional photoperiod sensitive varieties KDML105 and RD15 in the wet season only [15]. However, in addition to these mega-varieties, numerous other fragrant rice varieties are found in rice-growing countries of Asia [2]. The mutations on the Badh2 gene have led to the introduction of a premature stop codon to produce a protein that disables the Badh2 enzyme, leading to the accumulation of the $2 \mathrm{AP}$ substrate $[16,17]$. Further studies have revealed that numerous Badh2 alleles have been detected in diverse rice (Oryza sativa L.) germplasms. Fragrant rice accessions have been reported in three different genetic subpopulations of rice, including Group $V$ (Basmati and Sadri varieties), indica (Jasmine varieties), and tropical japonica [18]. There were many kinds of mutations in the Badh2 gene among different rice varieties, namely the common 8 bp deletion and three single nucleotide polymorphism sites (SNPs) in the 7th exon of the Badh2 gene (badh2.1 or badh2-E7) [9,19]; a 7-bp deletion in exon 2 (badh2-E2.1) [16]; a 7-bp insertion in exon 8 (badh2-E8) [20]; an additional eight alleles in exons 1 (badh2-E1.1), 10 (badh2-E10.1, badh2-E10.2, badh2-E10.3) 13 (badh2-E13.1 and badh2-E13.2) and 14 (badh2-E14.1 and badh2-E14.2) [12]; a 803-bp deletion between exons 4 and 5 (badh2-E4-5.2) [21]; a SNP at exon 10 (badh2-E10.4); a 75-bp deletion in exon 2 (badh2-E2.2); a 806-bp deletion between exons 4 and 5 (badh2-E4-5.1) [22]; a 3-bp deletion in the 5' UTR (badh2-p-5' UTR); an 8-bp insertion in the promoter [23]; an SNP at the exon1-intron1 junction (badh2-E1.2) [24]; and a 3-bp deletion in exon 12 (badh2-E12) [25].

Detailed studies have been conducted on the Badh2 gene in the aromatic rice germplasm of Myanmar [26,27], while outstanding commercial potential has been seen with Cambodian Phka varieties [28,29]. Several aromatic rice genotypes have been identified in Thailand, including those with special quality characteristics, e.g., those with pigmented pericarp, Leum Pua [30,31] and Hom-nil [32,33]. Accessions of a fragrant rice landrace, commonly known in some parts of northern Thailand's highlands as Bue Nur Moo (fragrant non-glutinous rice in the Karen language, here referred to as BNM), collected from farmers have been found to range widely both in the content of the aromatic compound 2AP and in the allelic variation of the aroma gene Badh2 [34]. Two accessions of the landrace were found, with the 2AP content approaching that of KDML105 and the same key deletion of the Badh2 gene, designated BNM-CMU and BNM4, while others did not have the important deletion, containing little to no fragrance. The BNM accessions also exhibited strong interaction effects of genotype $\times$ location on their grain quality characteristics, the head rice yield, gelatinization temperature and 2AP concentration [35]. The dominance of KDML105 in fragrant rice production is a relatively recent development in Thailand, where fragrance was once a common feature among the diversity of grain quality and adaptation traits of local rice landraces [36]. The present study set out to examine the grain quality of fragrant rice landraces from different regions of the country and to explore the allelic variation of the Badh2 gene.

In Thailand, Hom Mali is grown mostly from the variety Khao Dawk Mali 105 (KDML105), which was judged the world's best rice for two consecutive years at the 9th The Rice Trader (TRT) World Rice Conference 2017 [37]. However, in the following years the title was lost to the Cambodian Malys Angkor, and Vietnam's ST24 [38]. This causes some concern regarding the competitiveness of Thai Hom Mali. With an economic advantage of much higher price than non-aromatic rice, studies of aromatic rice germplasm should contribute towards maintenance and improvement in the rice quality standards.

Thailand is one of the most significant and unique countries for plant genetic resources and crop diversity, especially for rice (Oryza sativa L.) [39]. As Thailand lies partly in the center of rice diversity and in the region where rice was originally domesticated $[40,41]$, the characterization of local varieties and landrace collections are critical for the utilization of these resources. The farmers of this region still use their traditional or local cultivars, which not only suit their taste, but also provide crop 
security. Rice landraces have unique characteristics, including special quality traits such as their aroma, adaptation to the local environment and resistance to biotic and abiotic stress [42]. In addition, local rice contains high levels of genetic diversity, which provides an opportunity for plant breeders to select and improve new cultivars, which include both farmers and breeder's preferred traits. Hence, the development of new modern rice varieties has depended on the availability of genetic diversity [43-46].

Local fragrant rice germplasm of northern Thailand are high-value genetic resources as they contain special qualities. Many fragrant rice varieties of northern Thailand have been collected and selected by Chiang Mai University's breeding team for their high 2AP content in brown rice compared to the famous jasmine rice of Thailand. Initial studies focused on nine populations of one Thai fragrant rice landrace, Buer Ner Moo (BNM), from nine farmers and the two advanced breeding lines of JPD and, BNM-CMU, a cross between BNM and PTT1. The different local fragrant rice varieties showed different levels of $2 \mathrm{AP}$ content in brown rice, even within one variety name, due to the variation within landraces. Moreover, Badh2 allelic variation was found, which illustrated the badh2-E7 deletion on the Badh2 gene in BNM4, and BNM-CMU. They had high 2AP contents in brown rice with badh2-E7 deletion similar to that in KDML105 and PTT, the popular fragrant rice in Thailand [34]. In addition, a significant correlation was also found between $2 \mathrm{AP}$ content in brown rice and elevation. The 2AP content in brown rice of most of the Bue Ner Moo populations significantly increased when grown at high altitude [35]. Therefore, the local rice varieties that profess to be fragrant rice could have the potential to be developed into a new fragrant rice variety with geographical indications to increase income for the highland farmers. However, the studies of the fragrant gene in landrace rice are not well understood. To investigate germplasm resources for crop utilization and improvement programs, it is essential to describe and evaluate the morphological characteristics of existing germplasm resources to effectively identify and differentiate each cultivar, including identification of the interested genes' functional alleles.

Therefore, the objectives of this study were to evaluate the grain qualities, to investigate the allelic variation of the Badh2 gene in fragrant rice landraces, and to introduce a genetic resource for fragrant rice breeding programs by pure-line selection method or improved variety. This would also provide a basis for the development of other varieties to be consistent with the increasing demand of the market and consumers.

\section{Materials and Methods}

\subsection{Plant Materials}

Seed samples of fragrant rice landraces were collected from farmers' seed storages, including nine from the north, eight from the northeast and five from the south of Thailand. Two promising landraces previously identified by a rice breeding program at Chiang Mai University, BNM-CMU and Jow Pluak Dam (JPD), plus two elite fragrant varieties, Khao Dawk Mali 105 (KDML105) and Pathum Thani 1 (PTT1), and one high yielding non-fragrant variety Suphan Buri 1 (SPR1) were also included for comparison (Table 1). The seeds of each population were germinated in petri dishes for 14 days and then transplanted to $30 \mathrm{~cm}$ diameter undrained pots, with ten plants per pot, two pots per variety and two replications. The plants were grown as wetland rice, with $15 \mathrm{~cm}$ of water maintained above the soil surface at Chiang Mai University, Thailand, in the wet season of 2017/2018. At the tillering stage, leaf samples of each individual were collected and kept at $-20^{\circ} \mathrm{C}$ for DNA extraction. At grain maturity, seed samples were collected from 10 individual plants from each variety. 
Table 1. List of the fragrant rice landraces from three regions of Thailand, the elite varieties, and the advanced breeding lines studied for comparison.

\begin{tabular}{|c|c|c|c|c|}
\hline Rice Samples & Source & Code & Rice Variety Name & Source (Province) \\
\hline \multirow[t]{22}{*}{ Rice landrace } & North & BNM1 & Buer Ner Moo & Chiang Mai \\
\hline & & BNM2 & Buer Ner Moo & Chiang Mai \\
\hline & & BNM3 & Buer Ner Moo & Chiang Mai \\
\hline & & BNM4 & Buer Ner Moo & Chiang Mai \\
\hline & & BNM5 & Buer Ner Moo & Chiang Mai \\
\hline & & BNM6 & Buer Ner Moo & Chiang Mai \\
\hline & & BNM7 & Buer Ner Moo Pho Phi & Chiang Mai \\
\hline & & BNM8 & Buer Ner Moo Pho Phi & Chiang Mai \\
\hline & & BNM9 & Buer Ner Moo Phardo & Chiang Mai \\
\hline & Northeast & EL & E-Leuang & Loei \\
\hline & & $\mathrm{KH}$ & Kaow Hawm & Loei \\
\hline & & HS & Hawm Sa-ngium & Loei \\
\hline & & NDLP & Niaw Dam Luem Pua & Loei \\
\hline & & NU & Niaw Ubon & Loei \\
\hline & & PS & Pla Sew & Loei \\
\hline & & PLD & Phayaa Luem Dang & Loei \\
\hline & & SKH & Sew Kliang Hawm & Loei \\
\hline & South & BH62 & Baow Hawm 62 & Songkhla \\
\hline & & BH96 & Baow Hawm96 & Songkhla \\
\hline & & $\mathrm{HB}$ & Hawm Baow & Songkhla \\
\hline & & HBK & Hawm Bang Kaew & Songkhla \\
\hline & & HNK & Hawm Na Kaow & Songkhla \\
\hline \multirow[t]{2}{*}{ Breeding Line } & & BNM-CMU & Buer Ner Moo-CMU & $\begin{array}{c}\text { Department of } \\
\text { Agriculture }\end{array}$ \\
\hline & & JPD & Jow Pluak Dam & $\begin{array}{l}\text { Department of } \\
\text { Agriculture }\end{array}$ \\
\hline \multirow{3}{*}{ (as check varieties) } & & KDML105 & Khao Dawk Mali 105 & $\begin{array}{l}\text { Department of } \\
\text { Agriculture }\end{array}$ \\
\hline & & PTT1 & Pathum Thani 1 & $\begin{array}{l}\text { Department of } \\
\text { Agriculture }\end{array}$ \\
\hline & & SPR1 & Suphan Buri 1 & $\begin{array}{l}\text { Department of } \\
\text { Agriculture }\end{array}$ \\
\hline
\end{tabular}

\subsection{Seed Morphological Characterization}

The rice seed morphological characterization was conducted in accordance with the rice descriptor [47]. One hundred seeds of each sample were recorded individually for husk color, pericarp color, and awning. Seed sizes (grain length, width, and thickness) of unhusked seeds were measured by a Digital Vernier caliper (Draper Tools. Ltd., Chandler's Ford, United Kingdom) and classified into shape by the scheme of Matsuo graph [48]. Diversity in seed morphological characteristics was determined by the Shannon-Weaver index $\left(H^{\prime}\right)$ [49], defined as:

$$
H^{\prime}=-\sum_{i=1}^{k} p i \operatorname{In} p i
$$

where $k$ is the number of phenotypic classes for a trait and $\ln p i$ is natural log of the proportion of individuals in the $i$ th class of the trait.

\subsection{Grain Qualities}

Alkali spreading assay was performed to determine the gelatinization temperatures $[47,50]$. One hundred whole grains of milled rice from each experimental unit were placed in a petri dish, 
with 20 grains per dish. Subsequently, $10 \mathrm{~mL}$ of $1.7 \% \mathrm{KOH}$ was added to the petri dishes and kept at room temperature for $23 \mathrm{~h}$. After the $23 \mathrm{~h}$ incubation, the seeds were evaluated visually and given a score in accordance with the following seven point scale: (1) grain not affected; (2) grain swollen; (3) grain swollen, collar incomplete and narrow; (4) grain swollen, collar complete and wide; (5) grain split or segmented, collar complete and wide; (6) grain dispersed, merging with collar; and (7) grain completely dispersed and intermingled [51]. The alkali spreading value corresponded to the gelatinization temperature as follows: $1-2$, high temperature $\left(74-80^{\circ} \mathrm{C}\right)$ and hard when left to cool after cooking; $3-5$, intermediate temperature $\left(70-73^{\circ} \mathrm{C}\right)$ and medium hardness when left to cool after cooking; and 6-7, low temperature $\left(<70^{\circ} \mathrm{C}\right)$ and soft when left to cool after cooking [52]. KDML105 (low gelatinization temperature) and RD4 (high gelatinization temperature) were used as checks.

The fragrance status of each cultivars was identified by tasting the milled grain. One milliliter of $1.7 \%$ potassium hydroxide $(\mathrm{KOH})$ solution was applied to ten de-husked grains of each sample for $10 \mathrm{~min}$ at room temperature. The presence or absence of aroma was scored from 0-3: 0 for non-aromatic, (1) for slightly aromatic, (2) for moderately aromatic, and (3) for strongly aromatic. Each individual sample was inspected multiple times by 10 trained persons to confirm the phenotype (modified from the method of [53]).

\subsection{DNA Extraction and Badh2 Sequences}

In order to understand the genetic basis of the fragrance in Thai rice landraces, genomic DNA was extracted from leaf samples of each individual landraces using the CTAB method [54]. The DNA of each sample was examined and sequenced for the allele Badh2/badh 2 in exon 7 of Badh2 gene by using primers Badh2P5 (F: 5'-CCTCCGTGTTAATGCAGCTC-3', R: 5'-CATAGCAAGTGGCATGTACC-3') and Badh2P6 (F: 5'-GGTTGGTCTTCCTTCAGGTG-3', R: 5'-GTCCTTCCTAACTGCCTTCC-3') [21]. Each $50 \mu \mathrm{L}$ reaction contained $5 \mu \mathrm{L}$ 10X PCR buffer, $2.5 \mu \mathrm{L} 2.5 \mathrm{mM} \mathrm{MgCI}, 0.4 \mu \mathrm{L} 0.2 \mathrm{mM}$ Deoxyribonucleotides (dNTP), $5 \mu \mathrm{L}$ of each primer $(10 \mathrm{ng} / \mu \mathrm{L}), 0.4 \mu \mathrm{L} 0.5 \mathrm{U}$ Taq DNA polymerase (Thermo scientific), $40 \mu \mathrm{L} \mathrm{dH} 2 \mathrm{O}$ and $5 \mu \mathrm{L}$ genomic DNA ( $50 \mathrm{ng} / \mu \mathrm{L}$ ).

The amplification consisted of $94^{\circ} \mathrm{C} / 2 \mathrm{~min}$, followed by 40 cycles of $94{ }^{\circ} \mathrm{C} / 45 \mathrm{~s}, 50^{\circ} \mathrm{C} / 45 \mathrm{~s}$, and $72{ }^{\circ} \mathrm{C} / 1 \mathrm{~min}$, ending with $72{ }^{\circ} \mathrm{C}$ for $5 \mathrm{~min}$ as the final extension. Amplified products were genotyped using $1.5 \%$ agarose gel electrophoresis. Then, staining was carried out with MaestroSafe ${ }^{\mathrm{TM}}$ Nucleic Acid Stains (MAESTROGEN, Xiangshan, Hsinchu, Taiwan) and visualized under a UV transilluminator (BioDoc-It ${ }^{2}$ imaging systems, Analytik Jena, Upland, CA, USA) before samples were sent for sequencing at Macrogen, Inc. (Seoul, South Korea). The sequence size was $1323 \mathrm{bp}$, from intron 4 to intron 8 of the Badh2 gene.

The sequences were assembled using the DNA baser assembler v5.15.0 trial version (Heracle BioSoft S.R.L., Arges, Romania). The resulting contigs were used as BLAST queries using the data of Badh2/badh2, which were reported in the GenBank database of National Center for Biotechnology Information (NCBI, Bethesda, Maryland, USA) including the fragrant rice variety, SuYuNuo, and the non-fragrant rice variety, Nanjing11 (accession numbers EU7703020.1 and EU710319.1, respectively). The aligned sequences were imported into MEGA7 software [55] to compare sample sequences. Haplotype data were generated in DNAsp 5.10.01 [56]. The relationship between haplotypes was investigated by constructing median networks using Network version 5.0 [57]

\subsection{Statistical Analysis}

Analysis of variance was used to determine the significant difference between the different morphological characteristics at $p<0.05$ by statistical analysis STATISTIX 8.0 (Tallahassee, FL, USA). Least significant difference (LSD) was used to indicate the mean differences in the grain size, weight, and shape between the varieties in regards to grain morphology. $T$-tests were performed between the mean sensory test score of the varieties in each haplotype pool versus the score of each check line (high and low separately). 


\section{Results}

\subsection{Seed Morphological Variation of Thai Fragrant Rice Landraces}

The seed morphological traits of 22 Thai fragrant rice landrace populations are moderately heterogenous (Table 2 and Figure 1). The variation within populations was found in husk color and seed awning. A variation of husk color was found in BNM1, BNM2, BNM6, BNM7, HB, HBK, and HNK with straw colored husks mixed with brown furrows on straw. The Shannon-Weaver index $\left(\mathrm{H}^{\prime}\right)$ varied from 0.991 in HB to 0.098 in BNM2 and BNM6 while the rest of the landraces including BNM4 and BNM-CMU and three check varieties had uniform straw-colored husks. Ten Thai fragrant rice landrace populations, BNM-CMU and PTT1 had varying seed awning, from short awn and partly awn, while the remaining ten rice landrace populations, JPD, KDML105 and SPR1 were awnless. No variation was found within populations in the pericarp color; 26 rice populations had colorless pericarp except NDLP which had a purple pericarp (Table 3 and Table S2).

Table 2. Grain size and shape of paddy rice of 22 fragrant rice landrace accessions, 2 breeding lines, and 3 elite variety checks.

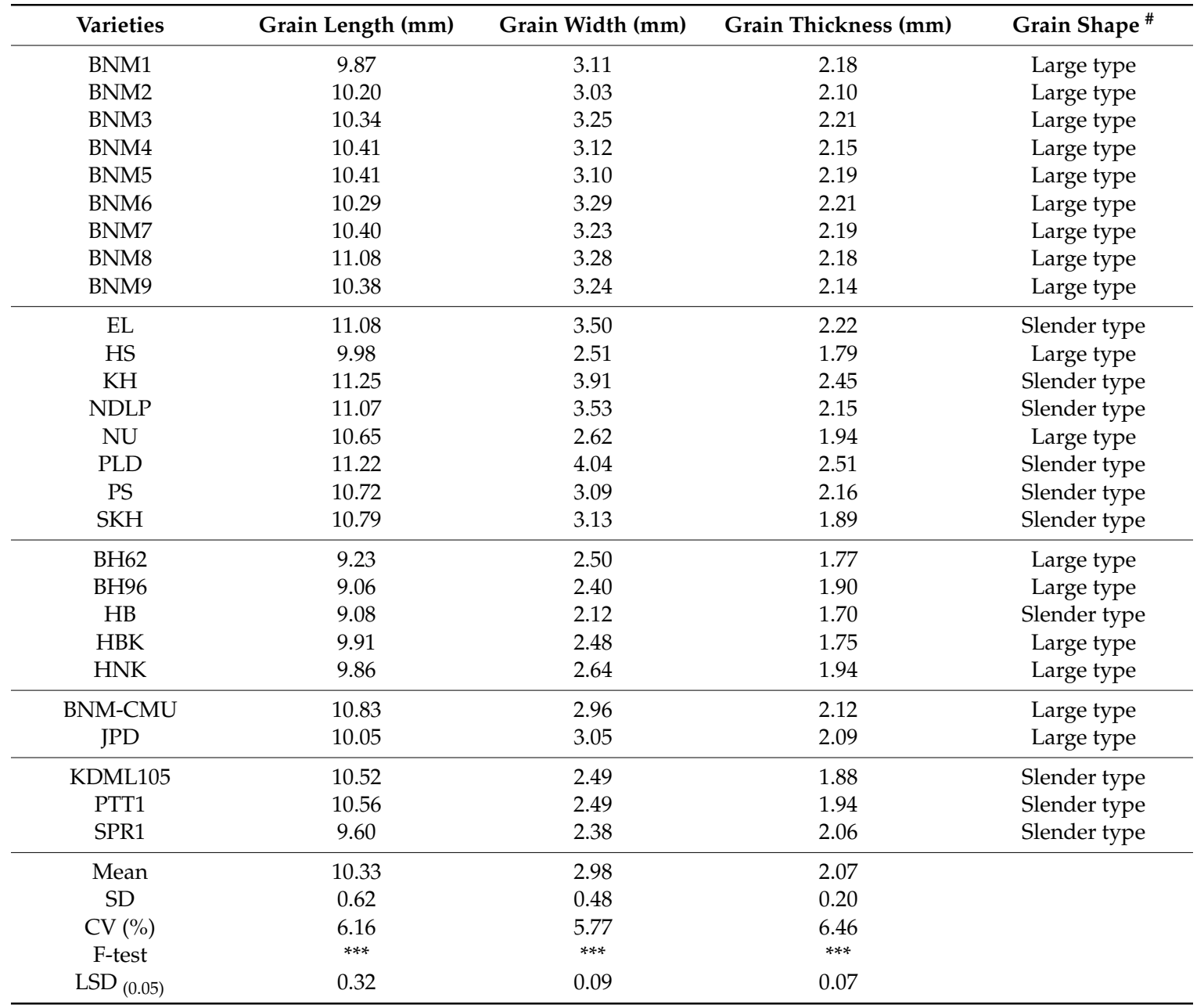

CV (\%), Coefficient of variation; LSD, least significant difference; **, Significant at the $1 \%$ level; ${ }^{*}$ classified with the scheme of Matsuo (1952). 
Table 3. Seed morphology of 22 landrace fragrant rice varieties, 2 breeding line varieties, and 3 check varieties.

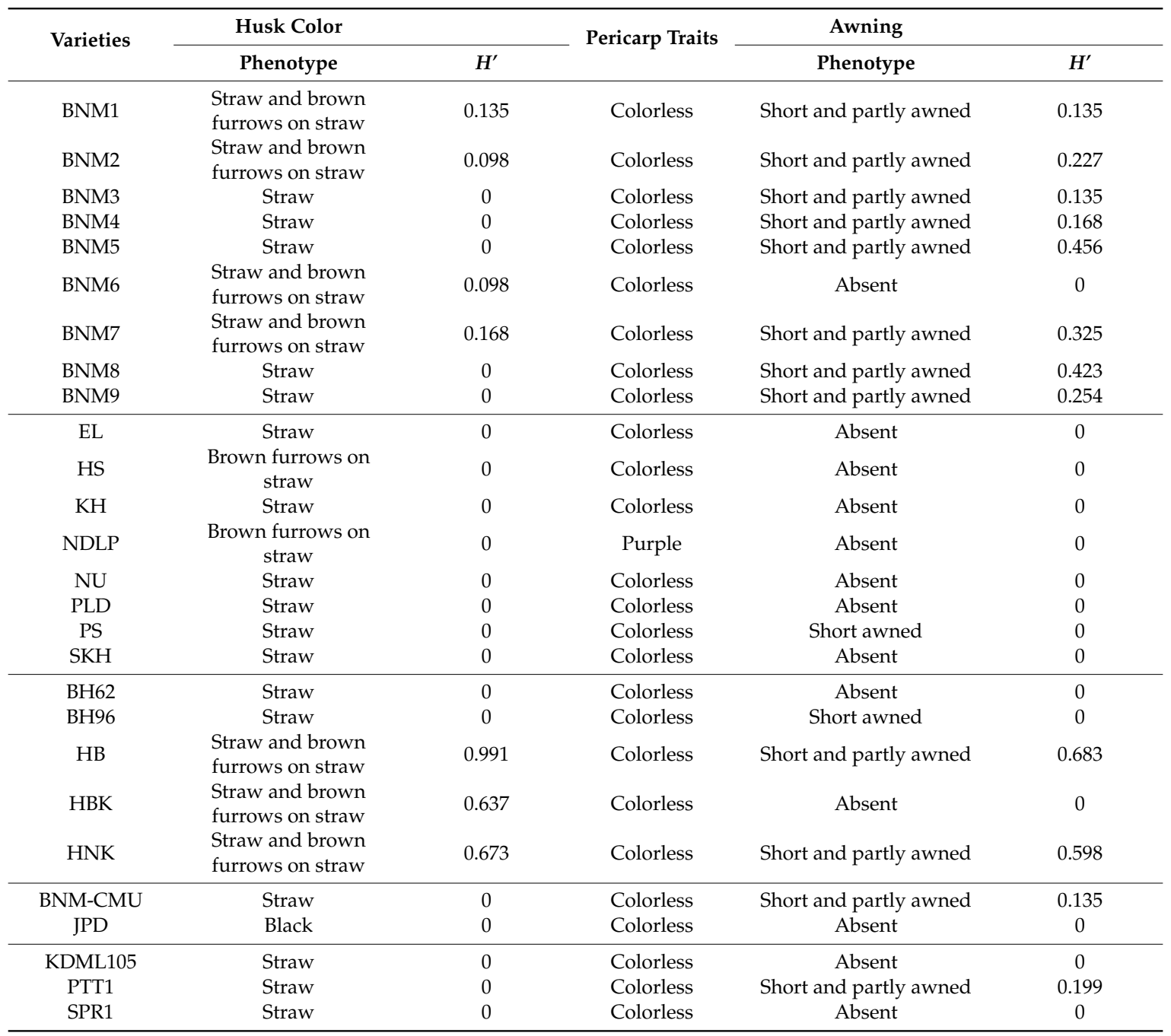

Sample $=100$ seeds $(n=100)$.

The grain size of the paddy rice was found to vary between the different rice samples collected $(p<0.05)$ (Table 2 and Table S1). The grain length, width, and thickness were found to vary at $10.33 \pm 0.62 \mathrm{~mm}, 2.98 \pm 0.48 \mathrm{~mm}$, and $2.07 \pm 0.20 \mathrm{~mm}$, respectively. The range of the grain length, width, and thickness of landrace rice were found to be $9.06-11.25 \mathrm{~mm}, 2.12-4.04 \mathrm{~mm}$, and $1.70-2.51 \mathrm{~mm}$, respectively. The two advanced breeding lines and two elite checks had ranges of 9.06-10.83 mm grain length, 2.38-2.96 mm width, and 1.88-2.12 mm thickness, and classification by the Matsuo (1952) scheme found fifteen of the rice landrace varieties along with the advanced breeding lines BNM-CMU and JPD belong to the large grain type, and the remaining seven as slender type, similar to the elite varieties, KDML105, PTT1 and SPR1 (Figure 1). 


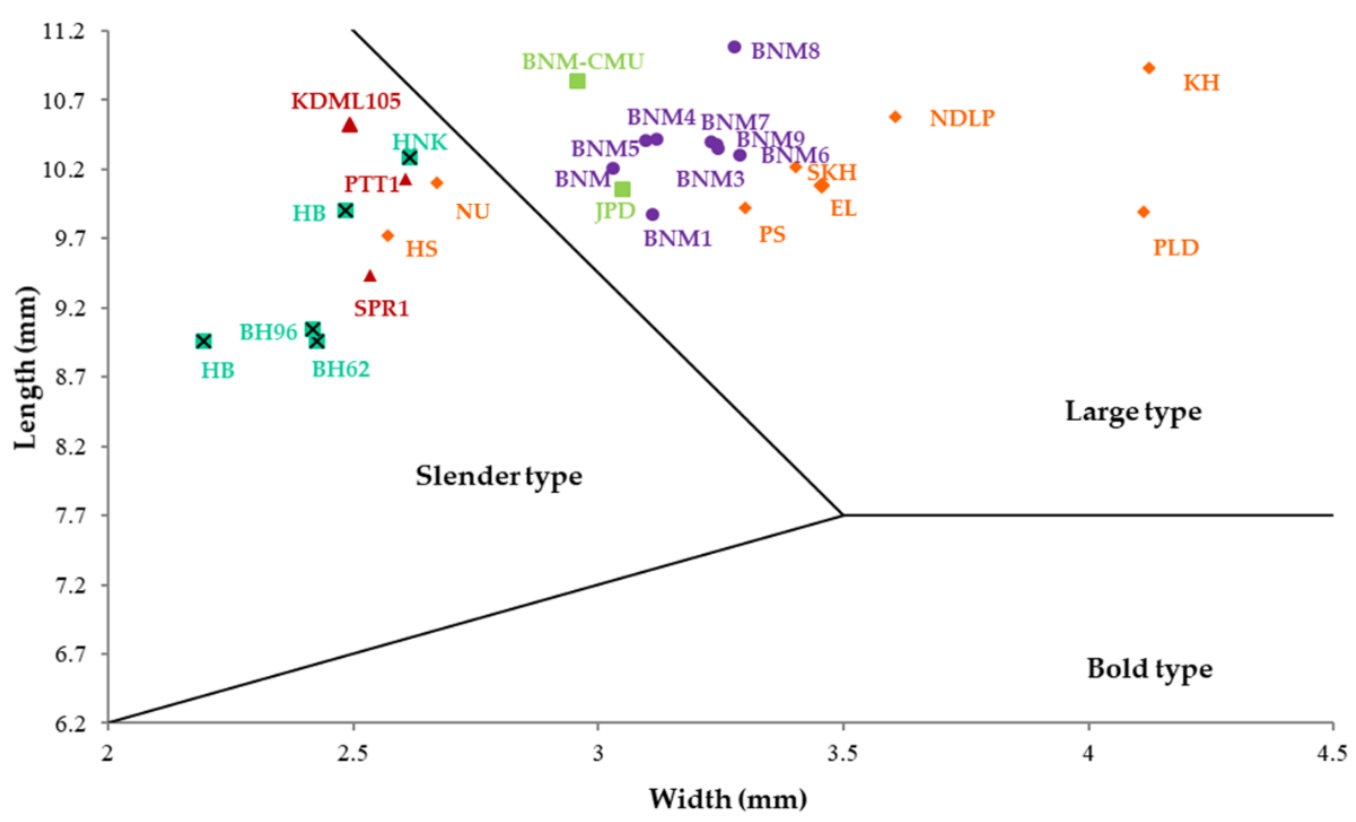

Figure 1. Shape of unhusked grains of 22 fragrant rice landrace varieties, with 2 breeding line varieties, and 3 check varieties, classed with the scheme of Matsuo (1952). Different colors and symbols identify different regions and rice groups: The nine purple circles, northern; the eight orange diamonds, the northeastern; the five blue squares, the southern; the two light green squares, promising landraces; and the three red triangles, elite fragrant varieties.

\subsection{Grain Quality}

Of the landraces locally recognized as fragrant when grown at Chiang Mai University and rated by a sensory test, KH, NDLP and PLD were found to be strongly aromatic in the same range as KDML105. Those found to be moderately aromatic similar to the elite variety PTT1 were BNM4, BNM-CMU and SKH. BH62, BH96, HS, JPD and PS were slightly aromatic, with no aroma detected in the remaining $43 \%$ of the germplasm (Table 4 and Table S4).

Gelatinization temperature assessed by alkali spreading assay was found to be low in four accessions of the landraces (BNM1, BNM2, EL and HB), comparable to KDML105 and PTT1, which remained soft when the cooked rice was allowed to cool to room temperature. Nine accessions (BNM3, BNM4, BNM5, BNM6, BNM7, BNM8, BNM9, JPD, and NU) had intermediate gelatinization temperatures similar to the advanced breeding line BNM-CMU, and the remaining $43 \%$ of the germplasm had high gelatinization temperatures similar to SPR1, a standard firm textured rice (Table S3). 
Table 4. Nucleotide sequences of Badh2/badh2 allele on exon 7, sensory test and alkaline test of 22 landrace fragrant rice varieties, 2 breeding line varieties, and 3 check varieties.

\begin{tabular}{|c|c|c|c|c|c|c|c|c|c|c|c|}
\hline \multirow{2}{*}{ Haplotype } & \multirow{2}{*}{ Variety } & \multicolumn{8}{|c|}{ Nucleotide Position } & \multirow{2}{*}{ Sensory Test ${ }^{\#}$} & \multirow{2}{*}{$\begin{array}{c}\text { Gelatinization } \\
\text { Temperature }\end{array}$} \\
\hline & & 2415 & 2901 & 2903 & 2905-2912 & 2913 & 3233 & 3386 & 3482 & & \\
\hline \multirow[t]{8}{*}{ Haplotype 1} & BNM4 & Insertion $\mathrm{G}$ & $\mathrm{T}$ & $\mathrm{T}$ & 8 deletion & $\mathrm{T}$ & G & C & $\mathrm{T}$ & Moderately aromatic & Medium \\
\hline & $\mathrm{KH}$ & Insertion G & $\mathrm{T}$ & $\mathrm{T}$ & 8 deletion & $\mathrm{T}$ & G & $\mathrm{C}$ & $\mathrm{T}$ & Strongly aromatic & High \\
\hline & NDLP & Insertion G & $\mathrm{T}$ & $\mathrm{T}$ & 8 deletion & $\mathrm{T}$ & G & $\mathrm{C}$ & $\mathrm{T}$ & Strongly aromatic & High \\
\hline & PLD & Insertion $\mathrm{G}$ & $\mathrm{T}$ & $\mathrm{T}$ & 8 deletion & $\mathrm{T}$ & G & C & $\mathrm{T}$ & Strongly aromatic & High \\
\hline & BNM-CMU & Insertion $\mathrm{G}$ & $\mathrm{T}$ & $\mathrm{T}$ & 8 deletion & $\mathrm{T}$ & G & $\mathrm{C}$ & $\mathrm{T}$ & Moderately aromatic & Medium \\
\hline & KDML105 & Insertion $\mathrm{G}$ & $\mathrm{T}$ & $\mathrm{T}$ & 8 deletion & $\mathrm{T}$ & G & $\mathrm{C}$ & $\mathrm{T}$ & Strongly aromatic & Low \\
\hline & PTT1 & Insertion $\mathrm{G}$ & $\mathrm{T}$ & $\mathrm{T}$ & 8 deletion & $\mathrm{T}$ & G & C & $\mathrm{T}$ & Moderately aromatic & Low \\
\hline & $\mathrm{SuYuNuo}^{\delta}$ & insertion G & $\mathrm{T}$ & $\mathrm{T}$ & 8 deletion & $\mathrm{T}$ & G & $\mathrm{C}$ & $\mathrm{T}$ & $N D$ & $N D$ \\
\hline \multirow[t]{6}{*}{ Haplotype 2} & BH62 & Insertion $\mathrm{G}$ & $\mathrm{A}$ & $\mathrm{A}$ & No deletion & $\mathrm{C}$ & G & $\mathrm{C}$ & $\mathrm{T}$ & Slightly aromatic & High \\
\hline & BH96 & Insertion $\mathrm{G}$ & A & A & No deletion & $\mathrm{C}$ & G & $\mathrm{C}$ & $\mathrm{T}$ & Slightly aromatic & High \\
\hline & HS & Insertion $\mathrm{G}$ & A & A & No deletion & $\mathrm{C}$ & G & $\mathrm{C}$ & $\mathrm{T}$ & Slightly aromatic & High \\
\hline & JPD & Insertion $\mathrm{G}$ & A & A & No deletion & C & G & C & $\mathrm{T}$ & Slightly aromatic & Medium \\
\hline & PS & Insertion G & A & $\mathrm{A}$ & No deletion & C & G & $\mathrm{C}$ & $\mathrm{T}$ & Slightly aromatic & High \\
\hline & SKH & Insertion G & A & A & No deletion & $\mathrm{C}$ & G & $\mathrm{C}$ & $\mathrm{T}$ & Moderately aromatic & High \\
\hline \multirow[t]{4}{*}{ Haplotype 3} & EL & Insertion $\mathrm{G}$ & A & $\mathrm{A}$ & No deletion & $\mathrm{C}$ & A & G & C & Non-aromatic & Low \\
\hline & HBK & Insertion G & A & A & No deletion & $\mathrm{C}$ & A & G & $\mathrm{C}$ & Non-aromatic & High \\
\hline & HNK & Insertion G & $\mathrm{A}$ & $\mathrm{A}$ & No deletion & C & $\mathrm{A}$ & G & $\mathrm{C}$ & Non-aromatic & High \\
\hline & $\mathrm{NU}$ & Insertion G & A & A & No deletion & $\mathrm{C}$ & A & G & $\mathrm{C}$ & Non-aromatic & Medium \\
\hline \multirow{11}{*}{ Haplotype 4} & BNM1 & - & A & A & No deletion & $\mathrm{C}$ & A & G & $\mathrm{C}$ & Non-aromatic & Low \\
\hline & BNM2 & - & A & A & No deletion & $\mathrm{C}$ & A & G & $\mathrm{C}$ & Non-aromatic & Low \\
\hline & BNM3 & - & A & A & No deletion & $\mathrm{C}$ & A & G & $\mathrm{C}$ & Non-aromatic & Medium \\
\hline & BNM5 & - & $\mathrm{A}$ & $\mathrm{A}$ & No deletion & C & A & G & $\mathrm{C}$ & Non-aromatic & Medium \\
\hline & BNM6 & - & A & $\mathrm{A}$ & No deletion & $\mathrm{C}$ & A & G & $\mathrm{C}$ & Non-aromatic & Medium \\
\hline & BNM7 & - & A & A & No deletion & $\mathrm{C}$ & A & G & $\mathrm{C}$ & Non-aromatic & Medium \\
\hline & BNM8 & - & $\mathrm{A}$ & $\mathrm{A}$ & No deletion & C & $\mathrm{A}$ & G & C & Non-aromatic & Medium \\
\hline & BNM9 & - & A & A & No deletion & $\mathrm{C}$ & A & G & $\mathrm{C}$ & Non-aromatic & Medium \\
\hline & HB & - & A & A & No deletion & C & A & G & C & Non-aromatic & Low \\
\hline & SPR1 & - & A & A & No deletion & $\mathrm{C}$ & A & G & C & Non-aromatic & High \\
\hline & Nanjing11 $\delta \delta$ & - & A & A & No deletion & $\mathrm{C}$ & A & G & C & $N D$ & $N D$ \\
\hline
\end{tabular}




\subsection{Badh2 Sequence Analysis}

Sequences of the Badh2 gene in exon 7 of 27 rice varieties were compared with the sequences of the two rice varieties, SuYuNuo and Nanjing1, obtained from the NCBI database, accession numbers EU7703020.1 and EU710319.1, respectively. The 1323 base pair segments of Badh2 gene, covering from intron 4 to intron 8 , revealed 8 base pair deletion in exon 7 and three single nucleotide polymorphisms (SNPs), similar to those found in the badh2-E7 allele of the check genotype SuYuNuo. Deletion of badh2-E7 was found in the strongly aromatic KH, NDLP, PLD and KDML105 and moderately aromatic BNM4, BNM-CMU, and PTT1.

Four haplotypes were identified in the analysis of the Badh2 gene in exon 7 sequence (Figure 2). The strongly aromatic KH, NDLP, PLD and moderately aromatic BNM4, together with the advanced breeding line BNM-CMU and the elite varieties KDML105 and PTT1 were identified as haplotype H1. Haplotype H2 comprised the moderately aromatic SKH, and the slightly aromatic BH62, BH96, HS, PS, and JPD, containing non-8 bp deletion and 3 SNP at 2901, 2903 and 2913. Haplotype H3 comprised EL, HBK, HNK and NU, displaying similar SNP to haplotype H2, except at the 3233 sites, which showed the G/A transition and the 3482 sites showing the $\mathrm{T} / \mathrm{C}$ transition. The last haplotype, $\mathrm{H} 4$, contained BNM1, BNM2, BNM3, BNM5, BNM6, BNM7, BNM8, BNM9 and HB, which had no aroma in the sensory test, along with the non-aromatic check, SPR1, containing similar sequences to non-aromatic Nanjing1 (Figure 3).

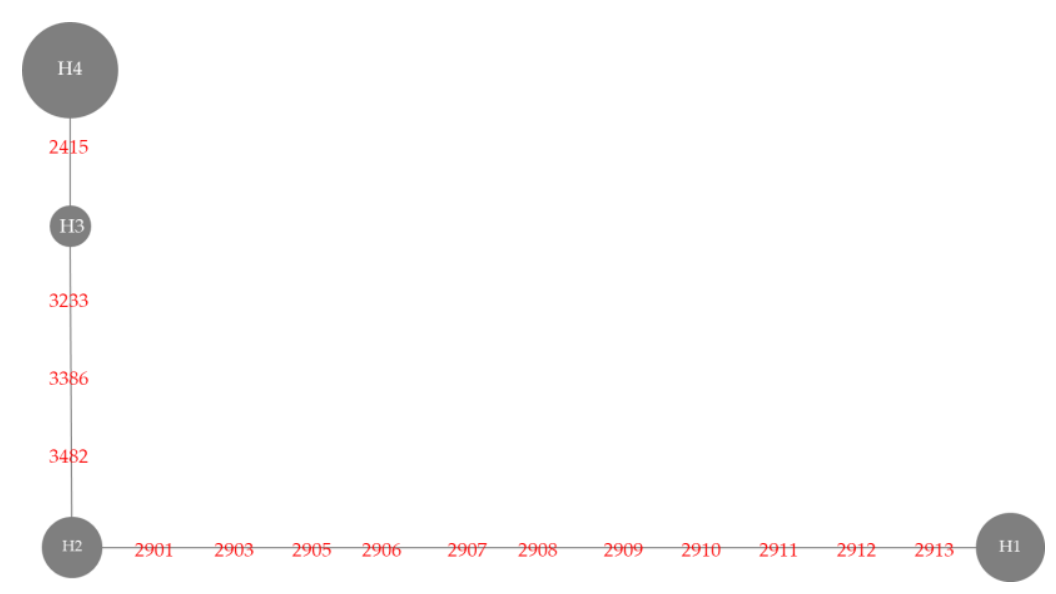

Figure 2. The haplotype network of the Badh2 gene. Letters inside the circle correspond to the haplotype name. The numbers on the lines indicate the position of nucleotide substitution polymorphisms. The size of each circle is proportional to the number of individuals varieties possessing that haplotype.

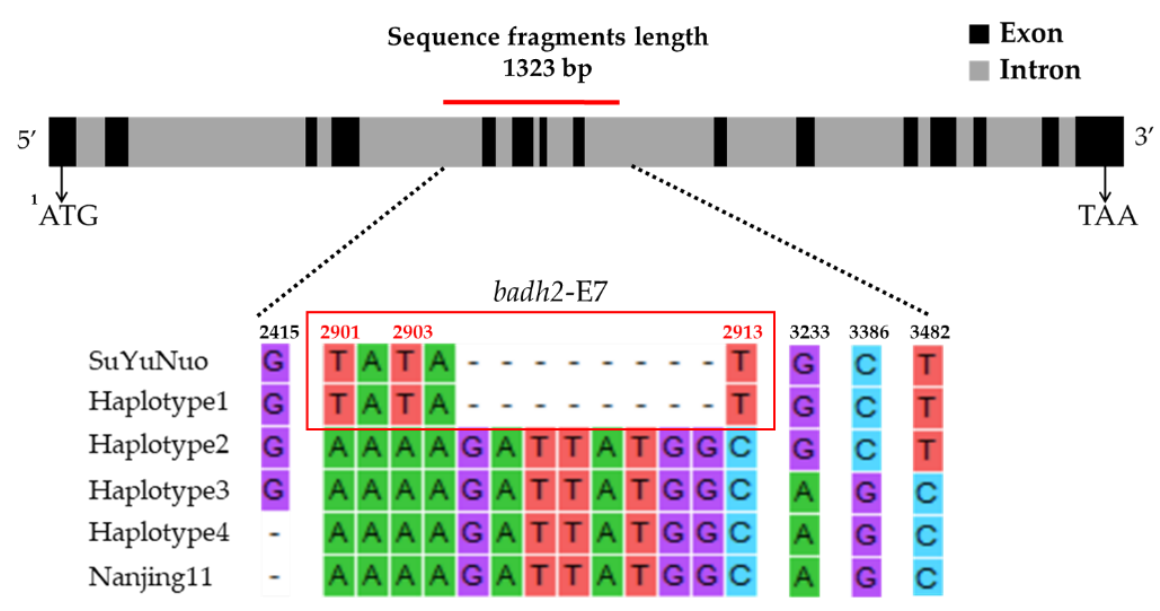

Figure 3. Extended haplotypes. Haplotype analysis of the sequence covering in the vicinity of badh2-E7 regions. 2415 site was in intron 4; 3233, 3386 and 3482 sites were in intron 8 of the Badh2 gene. 
Statistical T-test analysis identified significant differences between the sensory test score of the varieties in each haplotype pool versus the score of the high check line (Figure 4a) and low check line (Figure 4b).
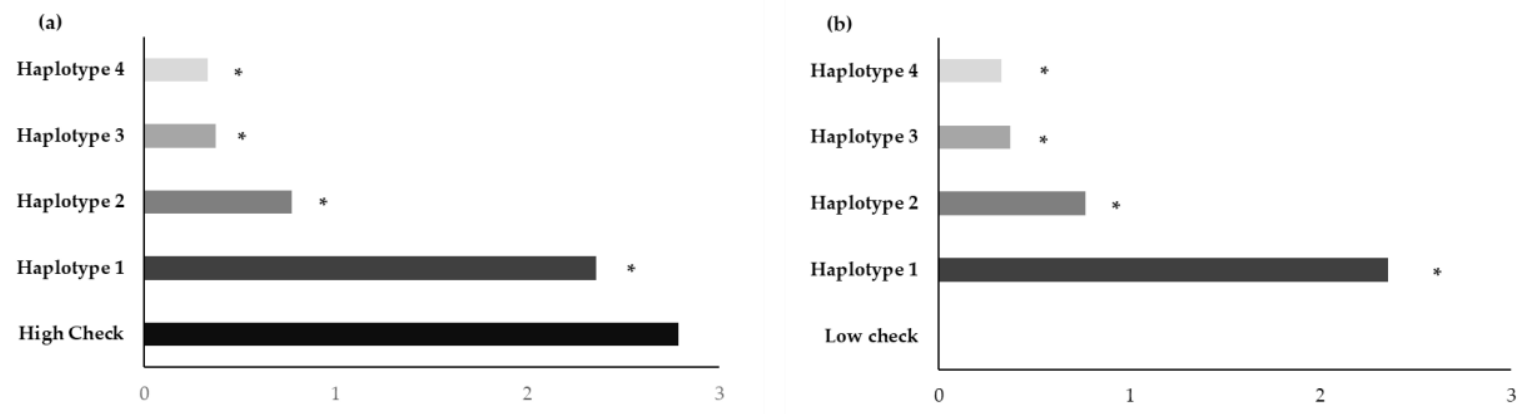

Figure 4. Statistical T-test analysis between the mean sensory test score of the varieties in each haplotype pool versus the score of high check line (a) and low check line (b); ${ }^{*}$, significant at the $5 \%$ level. Aroma was scored as 0 for non-aromatic, 1 for slightly aromatic, 2 for moderately aromatic, and 3 for strongly aromatic.

\section{Discussion}

The 22 rice landraces from northern, northeastern, and southern Thailand and two advanced breeding lines recognized locally as fragrant varieties have been found to vary considerably in their grain morphology, cooking quality, aroma and allelic variation of the fragrant gene Badh2. The landraces were classified mainly as large grain type, especially those from the highland of the north and northeast, where large grain type rice is preferred, as in the neighboring Lao PDR [58-60]. Diversity of local taste was also indicated in gelatinization temperature variation, ranging from low, in the same range as KDML105 and PTT1; intermediate, similar to the advanced breeding line BNM-CMU; to high as in the elite high yielding, non-aromatic variety SPR1. The premier Thai rice variety KDML105, with its long slender grain, low amylose content and low gelatinization temperature, has become the international standard for aromatic jasmine rice, just as it has long been in Thailand [61]. The grain quality features of KDML105 provide the benchmark for the selection of jasmine type grain quality in Thai breeding programs [31,36], and other areas [62-64], which commonly utilize KDML105 or other genotypes with similar grain quality characteristics as the parent. The rice landraces in this study clearly differentiate from KDML105 in their grain quality. The majority of the accessions belong to the large grain type. The few slender grain accessions either had high gelatinization temperatures or were non-aromatic when grown in Chiang Mai. Similar to the local Indian aromatic rice varieties of small and medium grain that are classed as non-Basmati [2], the local landraces in this study may be classed as non-jasmine type aromatic rice. It should be recognized as a distinctive and valuable set of rice genetic resources utilized and preserved on-farm. Unique among the landraces studied was NDLP, which is a glutinous rice with pigmented pericarp, sold as a premium priced, special quality rice [30]. It has potential health and pharmaceutical applications due to its anthocyanin content, phenolics and flavonoids, and high anti-oxidative properties [65].

The presence of the aromatic badh2-E7 allele encoding the production of the compound 2AP [19] confirmed the strong aroma in KH, NDLP and PLD, as in KDML105. However, the presence of badh2-E7 in the moderately aromatic BNM-CMU, BNM4 and SKH, along with PTT1 that was previously shown to have a significantly lower 2AP concentration than KDML105 [34], suggests some yet to be identified genotype-specific attenuating factors. Variation in aroma and 2AP content of KDML105 by environment and management in the lowlands, on the other hand, is well established [66-69]. A strong $\mathrm{G} \times \mathrm{E}$ interaction effect on the concentration of $2 \mathrm{AP}$, as well as the aroma by sensory test was found among accessions of Bue Nur Moo (BNM) grown at 330 and $800 \mathrm{~m}$ elevations, having no effect on the 2AP content of KDML105 [35]. The absence of aroma in the BNM accessions except for BMN4 in the 
present study, therefore, suggest a possible environmental effect on the aroma of these landraces from the highlands, and similarly, in the accessions from other regions. The absence of the badh2-E7 allele in many of the accessions, however, suggests that local perception of the aroma in rice may be complex and not determined simply by the compound 2AP.

The fragrance of rice is mainly controlled by the major gene, Badh2, but expression of the gene, and thus, the concentration of the aromatic compound 2AP is influenced by climatic conditions and crop management [70]. For instance, the soil conditions, nutrients, plant growth regulators, planting density, irrigation draining, harvesting, post-harvest practices and storage temperature all have an effect [71]. However, these rice landraces were all grown together under the same environment and management. The complete lack of aroma in the genotypes with haplotype 4 may either indicate a different local definition of aroma that does not involve the compound 2AP, or a case of misnaming as the haplotype also includes the non-aromatic elite variety SPR1. An as yet unknown regulatory mechanism controlling the expression of the Badh2 gene and the strength of the aroma is suggested by the variation in the aroma among the genotypes of haplotype 1, including the well-established difference between KDML105 and PTT1 [34]. The occurrence of deletion/insertion at other locations of the $\mathrm{Badh} 2$ gene or the presence of other genes related to aroma characteristics increasing or decreasing of 2AP formation in aromatic rice [10]. This appeared to have taken place with the difference in the nucleotide sequences between haplotype 1 and haplotype 2 . However, it is yet to be verified if the absence of the aroma in the genotypes with haplotype 3 is location-specific or not.

In conclusion, the aromatic rice landraces from different regions of Thailand had grain qualities that differentiated them from the elite varieties of KDML105 and PTT1. The majority were large grain with medium to high gelatinization temperatures in contrast to the slender grain with a low gelatinization temperature of the typical jasmine varieties KDML105 and PTT1. Only four of the landraces shared the badh2-E7 haplotype with the elite varieties of KDML105 and PTT1, and the previously selected BNM-CMU. The absence of the badh2-E7 allele in most of the accessions suggests that the 2AP compound may not be the only determinant of aroma in rice as perceived by local consumers. These locally recognized aromatic rice landraces make up a distinctive set of rice genetic resources preserved on-farm. One with commercial potential is exemplified by the glutinous genotype with pigmented pericarp, NDLP. Therefore, the landraces found to belong to the H1 group will be considered for further evaluation and introduced as genetic resources for a fragrant rice breeding program to develop highly palatable cultivars by pure-line selection or improving variety.

Factors affecting 2AP biosynthesis in fragrant rice will be identified in further work. Not only the fragrant genes, but also the environmental factors and crop management practices [72,73] should be examined to identify genes and develop functional markers for fragrant rice landrace breeding. These badh 2 alleles and functional markers are important for the development and identification of new fragrant rice varieties using marker-assisted selection.

Supplementary Materials: The following are available online at http://www.mdpi.com/2073-4395/10/6/779/s1, Table S1: Mean value and standard errors (3 replications) of the grain length $(\mathrm{mm})$, grain width (mm), and grain thickness $(\mathrm{mm})$ of paddy rice of 22 fragrant rice landrace accessions, 2 advanced breeding lines, and 3 elite variety checks; Table S2: Seed morphology of 22 landraces fragrant rice varieties, 2 breeding line varieties, and 3 check varieties $(n=100)$; Table S3: Alkali spreading test $(\%)$ at six levels of 22 landraces fragrant rice varieties, 2 breeding line varieties, and 3 check varieties $(n=100)$ Level; Table S4: Sensory scores by using 10 testers of 22 landraces fragrant rice varieties, 2 breeding line varieties, and 3 check varieties

Author Contributions: Conceptualization, T.P., S.J. and N.Y.; Funding acquisition, T.P., S.J. and B.R.; Investigation, P.C.-i. and T.P.; Methodology, P.C.-i., T.P., N.Y. and S.J.; Project administration, T.P. and S.J.; Supervision, T.P., B.R. and S.J.; Writing—original draft, P.C.-i. and T.P.; Writing—review and editing, P.C.-i., T.P., and B.R. All authors have read and agreed to the published version of the manuscript.

Funding: This research was funded by Thailand Research Fund (Research and Researcher for Industries) grant number PHD62I0031.

Acknowledgments: We are grateful to the farmers for sharing their knowledge and rice seeds. We thank the members of CMUPN lab, Chiang Mai University, for advice throughout this study and Asst Prof. Supranee Sitthiphrom, Dr. Anupong Wongtamee, and Dr. Nantiya Panomjan for collecting the rice seeds. The first author 
is the recipient of a Research and Researcher for Industries scholarship (PHD62I0031). This research work was partially supported by Chiang Mai University.

Conflicts of Interest: The authors declare no conflict of interest. The funders had no role in the design of the study; in the collection, analyses, or interpretation of data; in the writing of the manuscript, or in the decision to publish the results.

\section{References}

1. Sakthivel, K.; Sundaram, R.M.; Shobha Rani, N.; Balachandran, S.M.; Neeraja, C.N. Genetic and Molecular Basis of Fragrance in Rice. Biotechnol. Adv. 2009, 27, 468-473. [CrossRef] [PubMed]

2. Singh, R.K.; Singh, U.S.; Khush, G.S. Aromatic Rices; Oxford and India Book House Publishing Co. Pvt. Ltd.: New Delhi, India, 2000.

3. FAO Rice Price Update. Available online: http://www.fao.org/economic/est/publications/rice-publications/ the-fao-rice-price-update/en (accessed on 13 April 2020).

4. TREA. Thai Rice Exporters Association. Available online: http://www.thairiceexporters.or.th/price.htm (accessed on 13 April 2020).

5. Buttery, R.G.; Ling, L.C.; Juliano, B.O.; Turnbaugh, J.G. Cooked Rice Aroma and 2-Acetyl-1-Pyrroline. J. Agric. Food Chem. 1983, 31, 823-826. [CrossRef]

6. Ahn, S.N.; Bollich, C.N.; Tanksley, S.D. RFLP Tagging of a Gene for Aroma in Rice. Appl. Genet. 1992, 84, 825-828. [CrossRef]

7. Yi, M.; Nwe, K.T.; Vanavichit, A.; Chai-arree, W.; Toojinda, T. Marker Assisted Backcross Breeding to Improve Cooking Quality Traits in Myanmar Rice Cultivar Manawthukha. Field Crop. Res. 2009, 113, 178-186. [CrossRef]

8. Fitzgerald, T.L.; Waters, D.L.E.; Brooks, L.O.; Henry, R.J. Fragrance in Rice (Oryza Sativa) Is Associated with Reduced Yield under Salt Treatment. Environ. Exp. Bot. 2010, 68, 292-300. [CrossRef]

9. Bradbury, L.M.T.; Fitzgerald, T.L.; Henry, R.J.; Jin, Q.; Waters, D.L.E. The Gene for Fragrance in Rice. Plant Biotechnol. J. 2005, 3, 363-370. [CrossRef] [PubMed]

10. Itani, T.; Tamaki, M.; Hayata, Y.; Fushimi, T.; Hashizume, K. Variation of 2-Acetyl-1-Pyrroline Concentration in Aromatic Rice Grains Collected in the Same Region in Japan and Factors Affecting Its Concentration. Plant Prod. Sci. 2004, 7, 178-183. [CrossRef]

11. Vanavichit, A.; Kamolsukyeunyong, W.; Siangliw, M.; Siangliw, J.L.; Traprab, S.; Ruengphayak, S.; Chaichoompu, E.; Saensuk, C.; Phuvanartnarubal, E.; Toojinda, T.; et al. Thai Hom Mali Rice: Origin and Breeding for Subsistence Rainfed Lowland Rice System. Rice 2018, 11, 20. [CrossRef]

12. Kovach, M.J.; Calingacion, M.N.; Fitzgerald, M.A.; McCouch, S.R. The Origin and Evolution of Fragrance in Rice (Oryza Sativa L.). Proc. Natl. Acad. Sci. USA 2009, 106, 14444-14449. [CrossRef]

13. Singh, V.; Singh, A.K.; Mohapatra, T.; Ellur, R.K. Pusa Basmati 1121-A Rice Variety with Exceptional Kernel Elongation and Volume Expansion after Cooking. Rice 2018, 11, 19. [CrossRef]

14. Promotional and Public Relations Activities on Thai Hom Mali Rice Standard. Available online: http://www.dft.go.th/th-th/Service-DFT/Service-Information/DATA-Group-Product/Detail-DATAGroup-Product/ArticleId/7494/dft-Thai-jasmine-rice-22 (accessed on 1 April 2020).

15. Thai Ministry of Commerce. Thailand Standards for Rice. Available online: http://www.dft.go.th/th-th/ ShareDocument1/ArticleId/8860/-Thailand-Standards-for-Rice (accessed on 13 April 2020).

16. Shi, W.; Yang, Y.; Chen, S.; Xu, M. Discovery of a New Fragrance Allele and the Development of Functional Markers for the Breeding of Fragrant Rice Varieties. Mol. Breed. 2008, 22, 185-192. [CrossRef]

17. Sakthivel, K.; Rani, N.S.; Pandey, M.K.; Sivaranjani, A.K.P.; Neeraja, C.N.; Balachandran, S.M.; Madhav, M.S.; Viraktamath, B.C.; Prasad, G.S.V.; Sundaram, R.M. Development of a Simple Functional Marker for Fragrance in Rice and Its Validation in Indian Basmati and Non-Basmati Fragrant Rice Varieties. Mol. Breed. 2009, 24, 185-190. [CrossRef]

18. Gaur, A.; Wani, S.; Deepika, P.; Bharti, N.; Malav, A.; Shikari, A.; Bhat, A. Understanding the Fragrance in Rice. Rice Res. Open Access 2016, 4. [CrossRef]

19. Bradbury, L.M.T.; Henry, R.J.; Jin, Q.; Reinke, R.F.; Waters, D.L.E. A Perfect Marker for Fragrance Genotyping in Rice. Mol. Breed. 2005, 16, 279-283. [CrossRef] 
20. Amarawathi, Y.; Singh, R.; Singh, A.K.; Singh, V.P.; Mohapatra, T.; Sharma, T.R.; Singh, N.K. Mapping of Quantitative Trait Loci for Basmati Quality Traits in Rice (Oryza Sativa L.). Mol. Breed. Mol. Breed. New Strat. Plant Improv. 2008, 21, 49-65. [CrossRef]

21. Shao, G.N.; Tang, A.; Tang, S.Q.; Luo, J.; Jiao, G.A.; Wu, J.L.; Hu, P.S. A New Deletion Mutation of Fragrant Gene and the Development of Three Molecular Markers for Fragrance in Rice. Plant Breed. 2011, 130, $172-176$. [CrossRef]

22. Shao, G.; Tang, S.; Chen, M.; Wei, X.; He, J.; Luo, J.; Jiao, G.; Hu, Y.; Xie, L.; Hu, P. Haplotype Variation at Badh2, the Gene Determining Fragrance in Rice. Genomics 2013, 101, 157-162. [CrossRef]

23. Shi, Y.; Zhao, G.; Xu, X.; Li, J. Discovery of a New Fragrance Allele and Development of Functional Markers for Identifying Diverse Fragrant Genotypes in Rice. Mol. Breed. 2014, 33, 701-708. [CrossRef]

24. Ootsuka, K. Genetic Polymorphisms in Japanese Fragrant Landraces and Novel Fragrant Allele Domesticated in Northern Japan. Breed. Sci. 2014, 64, 115-124. [CrossRef]

25. He, Q.; Yu, J.; Kim, T.-S.; Cho, Y.-H.; Lee, Y.-S.; Park, Y.-J. Resequencing Reveals Different Domestication Rate for BADH1 and BADH2 in Rice (Oryza Sativa). PLoS ONE 2015, 10, e0134801. [CrossRef]

26. Myint, K.M.; Arikit, S.; Wanchana, S.; Yoshihashi, T.; Choowongkomon, K.; Vanavichit, A. A PCR-Based Marker for a Locus Conferring the Aroma in Myanmar Rice (Oryza Sativa L.). Appl. Genet. 2012, 125, 887-896. [CrossRef] [PubMed]

27. Oo, K.S.; Kongjaimun, A.; Khanthong, S.; Yi, M.; Myint, T.T.; Korinsak, S.; Siangliw, J.L.; Myint, K.M.; Vanavichit, A.; Malumpong, C.; et al. Characterization of Myanmar Paw San Hmwe Accessions Using Functional Genetic Markers. Rice Sci. 2015, 22, 53-64. [CrossRef]

28. Chan, S. Malys Angkor Crowned World's Best Rice. Available online: https://www.khmertimeskh.com/ 540271/malys-angkor-crowned-worlds-best-rice/ (accessed on 13 April 2020).

29. Bairagi, S.; Mohanty, S.; Custodio, M.C. Consumers' Preferences for Rice Attributes in Cambodia: A Choice Modeling Approach. J. Agribus. Dev. Emerg. Econ. 2019, 9, 94-108. [CrossRef]

30. Saetan, J. Seed Development and Maturation and Panicle Position on Seed Quality of Upland Rice Cv. Leum Pua. Master's Thesis, Prince of Songkla University, Songkla, Thailand, 2017.

31. TRKB. Rice Variety. Available online: http://www.ricethailand.go.th/rkb3/Varieties.htm (accessed on 13 April 2020).

32. Sadabpod, K.; Tongyonk, L.; Kangsadalampai, K. Effect of Hom Nil Rice and Black Glutinous Rice Extracts during Treatment of Chicken Extract with Sodium Nitrite Using Ames Test. J. Health Sci. Med. Res. 2014, 32, 139-149.

33. KURDI. Hom-nil, A Black Non-Glutinous Rice with High Nutritional Quality; Kasetsart University Research and Development Institute: KURDI. Available online: https://www3.rdi.ku.ac.th/?p=27452 (accessed on 13 April 2020).

34. Chan-in, P.; Jamjod, S.; Yimyam, N.; Pusadee, T. Diversity of BADH2 Alleles and Microsatellite Molecules in Highland Fragrant Rice Landraces. J. Agric. 2019, 35, $23-35$.

35. Tejakum, P.; Khumto, S.; Jamjod, S.; Yimyam, N.; Pusadee, T. Yield, Grain Quality and Fragrance of a Highland Fragrant Rice Landrace Variety, Bue Ner Moo. Khon Kaen Agric. J. 2019, 47, 317-326. [CrossRef]

36. Sarkarung, S.; Somrith, B.; Chitrakorn, S. Aromatic Rice of Thailand. In Aromatic Rices; Singh, R.K., Singh, U.S., Khush, G.S., Eds.; Mohan Primlani for Oxford and India Book House Publishing Co. Pvt. Ltd.: New Delhi, India, 2000; pp. 180-183.

37. The Rice Trader: TRT World's Best Rice News. Available online: https:/thericetrader.com/news/ (accessed on 13 April 2020).

38. Arunmas, P. Farmers Urge Action after Top Rice Fails to Win Prize. Available online: https://www. bangkokpost.com/business/1796249/farmers-urge-action-after-top-rice-fails-to-win-prize (accessed on 30 December 2019).

39. Harakotr, B.; Prompoh, K.; Boonyuen, S.; Suriharn, B.; Lertrat, K. Variability in Nutraceutical Lipid Content of Selected Rice (Oryza Sativa L. Spp. Indica) Germplasms. Agronomy 2019, 9, 823. [CrossRef]

40. Harlan, J.R. Crops and Man. Syst. Bot. 1977, 2, 227. [CrossRef]

41. Londo, J.P.; Chiang, Y.-C.; Hung, K.-H.; Chiang, T.-Y.; Schaal, B.A. Phylogeography of Asian Wild Rice, Oryza Rufipogon, Reveals Multiple Independent Domestications of Cultivated Rice, Oryza Sativa. Proc. Natl. Acad. Sci. USA 2006, 103, 9578-9583. [CrossRef] 
42. Pusadee, T.; Jamjod, S.; Chiang, Y.-C.; Rerkasem, B.; Schaal, B.A. Genetic Structure and Isolation by Distance in a Landrace of Thai Rice. Proc. Natl. Acad. Sci. USA 2009, 106, 13880-13885. [CrossRef]

43. Khush, G.S.; Toenniessen, G.H. Rice Biotechnology; International Rice Research Institute: Los Baños, Philippines, 1991.

44. Dowling, N.G.; Greenfield, S.M.; Fischer, K.S. Sustainability of Rice in the Global Food System; International Rice Research Institute: Los Baños, Philippines, 1998.

45. Pusadee, T.; Oupkaew, P.; Rerkasem, B.; Jamjod, S.; Schaal, B.A. Natural and Human-mediated Selection in a Landrace of Thai Rice (Oryza Sativa). Ann. Appl. Biol. 2014, 165, 280-292. [CrossRef]

46. Govindaraj, M.; Vetriventhan, M.; Srinivasan, M. Importance of Genetic Diversity Assessment in Crop Plants and Its Recent Advances: An Overview of Its Analytical Perspectives. Genet. Res. Int. 2015, 2015, e431487. [CrossRef] [PubMed]

47. IBPGR-IRRI Rice Advisory Committee and International Board for Plant Genetic Resources. Descriptors for Rice, Oryza Sativa L.; International Rice Research Institute: Los Baños, Philippines, 1980.

48. Matsuo, T. Genecological Studies on Cultivated Rice. Bull. Natl. Inst. Agric. Sci. Jpn. D 1952, 3, 1-111.

49. Shannon, C.E. A Mathematical Theory of Communication. Bell Syst. Tech. J. 1948, 27, 379-423. [CrossRef]

50. Bhattacharya, K.R. Gelatinization Temperature of Rice Starch and Its Determination. In Chemical Aspects of rice Grain Grain Quality; International Rice Research Institute: Los Baños, Philippines, 1979; pp. 231-250.

51. Mariotti, M.; Fongaro, L.; Catenacci, F. Alkali Spreading Value and Image Analysis. J. Cereal Sci. 2010, 52, 227-235. [CrossRef]

52. Perez, C.M.; Juliano, B.O. Modification of the Simplified Amylose Test for Milled Rice. Starch-Stärke 1978, 30, 424-426. [CrossRef]

53. Sood, B.C.; Siddiq, E.A. A Rapid Technique for Scent Determination in Rice. Indian J. Genet. Plant Breed. 1978, $38,268-275$.

54. Doyle, J.J.; Doyle, J.L. A Rapid DNA Isolation Procedure for Small Quantities of Fresh Leaf Tissue. Phytochem. Bull. 1987, 19, 11-15.

55. Kumar, S.; Stecher, G.; Tamura, K. MEGA7: Molecular Evolutionary Genetics Analysis Version 7.0 for Bigger Datasets. Mol. Biol. Evol. 2016, 33, 1870-1874. [CrossRef]

56. Librado, P.; Rozas, J. DnaSP v5: A Software for Comprehensive Analysis of DNA Polymorphism Data. Bioinformatics 2009, 25, 1451-1452. [CrossRef]

57. Bandelt, H.J.; Forster, P.; Röhl, A. Median-Joining Networks for Inferring Intraspecific Phylogenies. Mol. Biol. Evol. 1999, 16, 37-48. [CrossRef] [PubMed]

58. Heidhues, F.; Rerkasem, B. IRRI's Upland Rice Research Follow-up Review; Giar Science Council: Rome Italy, 2006.

59. Xiongsiyee, V.; Rerkasem, B.; Veeradittakit, J.; Saenchai, C.; Lordkaew, S.; Prom-u-thai, C.T. Variation in Grain Quality of Upland Rice from Luang Prabang Province, Lao PDR. Rice Sci. 2018, 25, 94-102. [CrossRef]

60. Jamjod, S.; Yimyam, N.; Lordkaew, S.; Prom-u-thai, C.; Rerkasem, B. Characterization of On-Farm Rice Germplasm in an Area of the Crop's Center of Diversity. Chiang Mai Univ. J. Nat. Sci. 2017, 16, 85-98. [CrossRef]

61. Juliano, B.O.; Duff, B. Rice Grain Quality as an Emerging Priority in National Rice Breeding Programmes. In Rice Grain Marketing and Quality Issues; International Rice Research Institute: Manila, Philippines, 1991; pp. 55-64.

62. Bollich, C.N. Release of New Rice Cultivar Jasmine 85 in USA. Int. Rice Res. Newsl. 1989, 14, 12.

63. Marchetti, M.A.; Bollich, C.N.; Webb, B.D.; Jackson, B.R.; McClung, A.M.; Scott, J.E.; Hung, H.H. Registration of 'Jasmine 85'Rice. Crop. Sci. 1998, 38, 896. [CrossRef]

64. Sha, X.Y.; Linscombe, S.D.; Jodari, F.; Chu, Q.R.; Groth, D.E.; Blanche, S.B.; Harrell, D.L.; White, L.M.; Oard, J.H.; Chen, M.H.; et al. Registration of 'Jazzman' Aromatic Long-Grain Rice. J. Plant Regist. 2011, 5, 304-308. [CrossRef]

65. Seekhaw, P.; Mahatheeranont, S.; Sookwong, P.; Luangkamin, S.; Neonplab, A.N.L.; Puangsombat, P. Phytochemical Constituents of Thai Dark Purple Glutinous Rice Bran Extract [Cultivar Luem Pua (Oryza Sativa L.)]. Chiang Mai J. Sci. 2018, 45, 1383-1395.

66. Suwanarit, A.; Kreetapirom, S.; Buranakarn, S.; Varanyanond, W.; Tungtrakul, P.; Somboonpong, S.; Rattapat, S.; Ratanasupa, S.; Romyen, P.; Wattanapayapkul, S.; et al. Effects of nitrogen fertilizer on grain qualities of Khaw Dauk Mali-105 aromatic rice. J. The Kasetsart (Nat. Sci.) 1996, 30, 458-474. 
67. Leesawatwong, M.; Jamjod, S.; Rerkasem, B.; Pinjai, S. Determinants of a Premium-Priced, Special-Quality Rice. Int. Rice Res. Notes 2003, 28, 33.

68. Yoshihashi, T.; Huong, N.T.T.; Inatomi, H. Precursors of 2-Acetyl-1-Pyrroline, a Potent Flavor Compound of an Aromatic Rice Variety. J. Agric. Food Chem. 2002, 50, 2001-2004. [CrossRef]

69. Yoshihashi, T.; Nguyen, T.T.H.; Kabaki, N. Area Dependency of 2-Acetyl-1-Pyrroline Content in an Aromatic Rice Variety, Khao Dawk Mali 105. Jpn. Agric. Res. Q. Jarq 2004, 38, 105-109. [CrossRef]

70. Golam, F.; Norzulaani, K.; Jennifer, A.H.; Subha, B.; Zulqarnain, M.; Osman, M.; Nazia, A.M.; Zulqarnian, M.; Mohammad, O. Evaluation of Kernel Elongation Ratio and Aroma Association in Global Popular Aromatic Rice Cultivars in Tropical Environment. Afr. J. Agric. Res. 2010, 5, 1515-1522.

71. Wakte, K.; Zanan, R.; Hinge, V.; Khandagale, K.; Nadaf, A.; Henry, R. Thirty-Three Years of 2-Acetyl-1-Pyrroline, a Principal Basmati Aroma Compound in Scented Rice (Oryza Sativa L.): A Status Review. J. Sci. Food Agric. 2016. [CrossRef]

72. Gay, F.; Maraval, I.; Roques, S.; Gunata, Z.; Boulanger, R.; Audebert, A.; Mestres, C. Effect of Salinity on Yield and 2-Acetyl-1-Pyrroline Content in the Grains of Three Fragrant Rice Cultivars (Oryza Sativa L.) in Camargue (France). Field Crop. Res. 2010, 117, 154-160. [CrossRef]

73. Li, M.; Ashraf, U.; Tian, H.; Mo, Z.; Pan, S.; Anjum, S.A.; Duan, M.; Tang, X. Manganese-Induced Regulations in Growth, Yield Formation, Quality Characters, Rice Aroma and Enzyme Involved in 2-Acetyl-1-Pyrroline Biosynthesis in Fragrant Rice. Plant Physiol. Biochem. 2016, 103, 167-175. [CrossRef]

(C) 2020 by the authors. Licensee MDPI, Basel, Switzerland. This article is an open access article distributed under the terms and conditions of the Creative Commons Attribution (CC BY) license (http://creativecommons.org/licenses/by/4.0/). 